\title{
Expression and Distribution of Renal Vacuolar Proton-translocating Adenosine Triphosphatase in Response to Chronic Acid and Alkali Loads in the Rat
}

\author{
Bahar Bastani, ** Henry Purcell,** Philip Hemken," David Trigg, ${ }^{\star}$ and Stephen Gluck** \\ Departments of ${ }^{*}$ Medicine, and ${ }^{\S}$ Cell Biology and Physiology, Washington University School of Medicine, \\ and ${ }^{\ddagger}$ Renal Division, Jewish Hospital of St. Louis, St. Louis, MO 63110
}

\begin{abstract}
Renal hydrogen ion excretion increases with chronic acid loads and decreases with alkali loads. We examined the mechanism of adaptation by analyzing vacuolar proton-translocating adenosine triphosphatase ( $\mathrm{H}^{+}$ATPase) 31-kD subunit protein and mRNA levels, and immunocytochemical distribution in kidneys from rats subjected to acid or alkali loads for $1,3,5,7$, and $14 \mathrm{~d}$. Acid- and alkali-loaded rats exhibited adaptive responses in acid excretion, but showed no significant changes in $\mathrm{H}^{+}$ATPase protein or mRNA levels in either cortex or medulla. In contrast, there were profound adaptive changes in the immunocytochemical distribution of $\mathrm{H}^{+}$ATPase in collecting duct intercalated cells. In the medulla, $\mathrm{H}^{+}$ATPase staining in acidloaded rats shifted from cytoplasmic vesicles to plasma membrane, whereas in alkali-loaded rats, cytoplasmic vesicle staining was enhanced, and staining of plasma membrane disappeared. In the cortical collecting tubule, acid loading increased the number of intercalated cells showing enhanced apical $\mathrm{H}^{+}$ATPase staining and decreased the number of cells with basolateral or poorly polarized apical staining. The results indicate that both medulla and cortex participate in the adaptive response to acid and alkali loading by changing the steady-state distribution of $\mathrm{H}^{+}$ATPase, employing mechanisms that do not necessitate postulating interconversion of intercalated cells with opposing polarities. (J. Clin. Invest. 1991. 88:126-136.) Key words: acid-base $\bullet$ adaptation $\bullet$ kidney $\bullet$ proton pump • acidosis
\end{abstract}

\section{Introduction}

To maintain acid-base homeostasis, the kidney increases acid excretion during increased intake or generation of acid, and it increases the excretion of bicarbonate during net alkali intake. The proximal tubule reabsorbs up to $90 \%$ of the filtered bicarbonate. $\mathrm{Na}^{+} / \mathrm{H}^{+}$antiport is the major mechanism for proton secretion in this segment (1), although a vacuolar-type protontranslocating adenosine triphosphatase $\left(\mathrm{H}^{+}\right.$ATPase $),{ }^{1}$ also pres-

Address reprint requests to Dr. Bastani, Renal Division, Jewish Hospital, 216 South Kingshighway Blvd., St. Louis, MO 63110.

Received for publication 16 October 1990 and in revised form 22 January 1991.

1. Abbreviations used in this paper: $\mathrm{H}^{+}$ATPase, proton-translocating adenosine triphosphatase. Intercalated cells showing $\mathrm{H}^{+}$ATPase staining: A, apically stained; B, basolaterally stained; BA, basolateral and apical pole staining; $D$, diffusely stained; PPA, poorly polarized apically stained; PPB, poorly polarized basolaterally stained; WPA, wellpolarized apically stained; WPB, well-polarized basolaterally stained.

J. Clin. Invest.

(c) The American Society for Clinical Investigation, Inc. 0021-9738/91/07/0126/11 \$2.00

Volume 88, July 1991, 126-136 ent in the apical membrane (2-4), contributes to up to $40 \%$ of the overall proximal $\mathrm{H}^{+}$secretion in rat (5-7). Physiologic studies have revealed increased or reduced $\mathrm{Na}^{+} / \mathrm{H}^{+}$antiport activity and bicarbonate reabsorption in the proximal tubule in response, respectively, to metabolic acidosis $(8-14)$ or metabolic alkalosis $(12,13)$. Changes in $V_{\max }$ for $\mathrm{Na}^{+} / \mathrm{H}^{+}$antiport have been demonstrated, suggesting that the number of functioning antiporters is modified. Whether changes in the vacuolar $\mathbf{H}^{+}$ ATPase contribute to proximal tubule adaptation in acid-base homeostasis remains unresolved at the present time.

The final regulation of acid excretion occurs in the distal nephron, where hydrogen ion transport is carried out by an electrogenic vacuolar-type proton pump (15-22). Distal acid excretion is regulated primarily by the intercalated cells, specialized collecting duct cells which are able to maintain dense arrays of the $\mathrm{H}^{+}$ATPase in a polarized distribution on the plasma membrane to implement net proton or bicarbonate secretion $(2,21,23)$. Physiologic studies have shown that collecting duct hydrogen ion transport changes with the acid-base status of the animal. In rabbits, the cortical collecting tubule secretes bicarbonate under control conditions (24-32), but exhibits net $\mathrm{H}^{+}$secretion in acid-loaded animals $(24,26,29,32)$. The outer medullary outer and inner stripes secrete $\mathrm{H}^{+}$regardless of the acid-base status of the animal $(17,24,31,32)$, and the rates of secretion do not increase with acid-loading $(26,31$, 32). The inner medulla also has $\mathrm{H}^{+}$secretion (33-37), which is augmented by acidemia $(33,35,36)$.

Several investigators have attempted to examine the mechanistic basis of collecting duct acid-base adaptation. Madsen and Tisher (38), using electron microscopic methods, observed a $50 \%$ increase in the luminal membrane surface density in the outer medulla of kidneys from rats subjected to acid loading for $18 \mathrm{~d}$. They concluded that the response resulted from fusion of tubulovesicular structures seen in the apical cytoplasm with the luminal membrane, and suggested that these might contain proton pumps. Schwartz, Satlin, and colleagues (39-41), examined adaptation in the cortical collecting duct using physiologic measurements of $\mathrm{H}^{+}$transport, acridine orange staining, and endocytosis assays. They found evidence for two morphologic subtypes of intercalated cells with acidic vesicles polarized either to the apical or basolateral region, which were designated as $\mathrm{H}^{+}$-secreting or bicarbonate-secreting cells. In acid-loaded rabbits, they noted a change in the percent of the two intercalated cell subtypes, and concluded that the cells changed their polarity (39). Satlin and Schwartz (41) extended the initial studies, showing that intercalated cells underwent morphologic changes in vitro in isolated collecting tubules exposed to an acid bath. They again interpreted the results as showing a reversal of intercalated cell polarity. While these studies examined important aspects of intercalated cell morphology and function during adaptation, they did not use direct assays to examine the vacuolar $\mathrm{H}^{+}$ATPase in these cells. Garg and Narang (42), and Sabatini et al. (43) examined changes in $N$-ethylmaleimide-in- 
hibitable ATPase activity, a putative assay for vacuolar $\mathrm{H}^{+}$ ATPase activity (44), in acid-loaded rats. In the study of Garg and Narang, increased activity was found in the cortical and medullary collecting tubules, whereas in the study of Sabatini et al., activity was increased in the thick ascending limb and cortical collecting tubule. From these results, the investigators suggested that adaptation occurred by a change in the enzymatic activity of the proton ATPase in distal segments.

The purpose of the present study was to use new methods for analyzing the quantity and distribution of the renal vacuolar $\mathrm{H}^{+}$ATPase in order to evaluate its role in the cellular response of the kidney to chronic acid-base adaptation. The renal vacuolar $\mathrm{H}^{+}$ATPase is a large molecular weight protein with several different subunits in its cytoplasmic domain (20-22). We previously reported the purification and properties of vacuolar $\mathrm{H}^{+}$ATPase from mammalian kidney medulla $(19,22)$ and cortex (20), and the isolation of a cDNA clone for the 31-kD subunit (45). Using affinity-purified antibodies against three different subunits $(31,56$, and $70 \mathrm{kD})$ of the bovine kidney proton pump, we described the immunocytochemical distribution of vacuolar $\mathrm{H}^{+}$ATPase in normal rat kidney (2), and showed that several morphologically different types of intercalated cells exist in the cortical collecting duct $(2,23)$. In this investigation, we analyze changes in the kidney in response to chronic acid and alkali loading by measuring $\mathrm{H}^{+}$ATPase protein and mRNA levels and by mapping the distribution of the enzyme by immunocytochemistry.

\section{Methods}

Experimental protocol. Adult male Sprague-Dawley rats weighing 180$200 \mathrm{~g}$ were divided into three groups: group 1 (controls) had free access to tap water; group 2 (alkali-loaded rats) had $280 \mathrm{mM}(2.35 \%) \mathrm{Na}$ $\mathrm{HCO}_{3}+1 \%$ sucrose in their drinking water; and group 3 (acid-loaded rats) had $280 \mathrm{mM}(1.5 \%) \mathrm{NH}_{4} \mathrm{Cl}+1 \%$ sucrose in their drinking water. All rats were fed a standard rodent laboratory diet. On days 1, 3, 5, 7, 14 of the study protocol, rats were anesthetized by intraperitoneal injection of pentobarbital $(50 \mathrm{mg} / \mathrm{kg})$, and after $45 \mathrm{~min}$, samples of bladder urine and aortic blood were collected on ice for $\mathrm{pH}$ and $\mathrm{PCO}_{2}$ determinations. Both kidneys were removed immediately and processed for $\mathrm{H}^{+}$ ATPase $31-\mathrm{kD}$ subunit mRNA and protein content, and for $31-\mathrm{kD}$ subunit tissue immunocytochemistry.

Quantitation of $m R N A$. The kidney cortex and medulla were separated rapidly and frozen in liquid $\mathrm{N}_{2}$. Total RNA was prepared with a standard protocol $(46)$ and stored at $-70^{\circ} \mathrm{C}$. An estimate of the total RNA in each sample was obtained by the $A_{260}$ absorbance. For RNA blot analysis, $10 \mu \mathrm{g}$ of each sample was separated by electrophoresis on a $6 \%$ formaldehyde $1 \%$ agarose denaturing gel (47). All RNA samples were screened for degradation by the appearance of the $28 \mathrm{~S}$ and $18 \mathrm{~S}$ ribosomal RNA. RNA was transferred to Gene Screen Plus membranes (Dupont Biotechnology Systems, New England Nuclear Research Products, Boston, MA) with a Vacu-blot apparatus (Hoefer Scientific Instruments, Inc., San Francisco, CA). Northern blot hybridization was performed according to protocol (47) using a $\left[\alpha-{ }^{32} \mathrm{P}\right] \mathrm{dCTP}$ labeled full-length cDNA probe for the rat vacuolar $\mathrm{H}^{+}$ATPase $31-\mathrm{kD}$ subunit prepared by random priming (Amersham Corp., Arlington Heights, IL). Autoradiography was performed by exposing XAR film (Eastman Kodak Co., Rochester, NY) to the membranes at $-70^{\circ} \mathrm{C}$ for $24 \mathrm{~h}$. RNA blots of all samples showed a single transcript at $\sim 1.2 \mathrm{~kb}$ with minimal degradation, and the same samples were then used in quantitative dot- and slot-blot assays. For the dot-blot and slot-blot hybridization assays (48), $6 \mu \mathrm{g}$ of cortical and $2 \mu \mathrm{g}$ of medullary samples, denatured in $6 \%$ formaldehyde and $50 \%$ formamide, were applied to Gene Screen Plus membranes in dot-blot and slot-blot manifolds (VacuDot-VS and VacuSlot-VS, respectively; American Bionetics,
Inc., Hayward, CA). Probe hybridization and autoradiography of the membranes were performed as before. The intensity of the hybridization signals was quantified by transmittance densitometry. As a control assay for the amount of RNA applied, all membranes were stripped of the $31-\mathrm{kD}$ cDNA probe, and subsequently reprobed with a randomprimed $\left[\alpha_{-}{ }^{32} \mathrm{P}\right] \mathrm{dCTP}$-labeled cDNA for rat $\beta$-actin (kindly provided by Dr. Karen O'Malley, Washington University). Ratios of the densitometry values of the $31-\mathrm{kD} \mathrm{H}^{+}$ATPase mRNA to the $\beta$-actin mRNA were used to compare the expression of $31-\mathrm{kD} \mathrm{H}^{+}$ATPase mRNA in the three groups of rats.

31-kD $H^{+}$ATPase protein assay. E11, a monoclonal antibody to the 31-kD subunit of the vacuolar $\mathrm{H}^{+}$ATPase was used for the dot immunobinding $(49,50)$. Microsomes from cortex or medulla were prepared by grinding tissue in ice-cold homogenizing buffer $(250 \mathrm{mM}$ sucrose, $5 \mathrm{mM}$ Tris, $1 \mathrm{mM} \mathrm{KHCO}{ }_{3}, 1 \mathrm{mM}$ EGTA, $0.5 \mathrm{mM}$ DTT, 1 mM PMSF) with 15 strokes, at a pestle speed of $1,000 \mathrm{rpm}$, in a $1-$ or 2-ml teflon-glass homogenizer. Total protein in each sample was quantified by the bicinchoninic acid method (Pierce Chemical Co., Rockford, IL) using the manufacturer's instructions. The microsomes were solubilized with a $1: 3$ (vol/vol) mixture of $0.625 \%$ SDS to microsomes; 5 and $10 \mu \mathrm{g}$ of solubilized protein samples were applied, in duplicate, to a nitrocellulose membrane in a dot-blot manifold. All subsequent steps were performed at $25^{\circ} \mathrm{C}$. Membranes were incubated in Blotto-Tween ( $5 \% \mathrm{wt} / \mathrm{vol}$ nonfat dry milk, $0.2 \%$ Tween $20,5 \mathrm{mM}$ Na azide in PBS) for $1 \mathrm{~h}$ to block nonspecific binding. They were subsequently incubated with E11 as ascites diluted 1:50 (vol/vol) in Blotto-Tween for $1 \mathrm{~h}$. Membranes were rinsed in Blotto-Tween for $1 \mathrm{~h}$ and then incubated with ${ }^{125}$ I-labeled goat anti-mouse IgG (Fisher Biotech, Fisher Scientific Co., Pittsburgh, PA) $\left(10^{6} \mathrm{cpm} / \mathrm{ml}\right)$ in Blotto-Tween for $1 \mathrm{~h}$. Membranes were washed four times in Blotto-Tween and once in PBS before autoradiography. Duplicate samples of the electroeluted 31-kD subunit $(0.5$ and $1.0 \mu \mathrm{g})$ from affinity-purified bovine kidney $\mathrm{H}^{+}$ATPase (20) were applied to each membrane as standards. Quantitation of anti-31-kD binding was expressed as the densitometric ratio of binding to the microsomal samples (duplicate 5 and $10 \mu \mathrm{g}$ ) over binding to the 1 $\mu \mathrm{g}$ of affinity-purified $31-\mathrm{kD} \mathrm{H}^{+}$ATPase on the same membrane.

Immunocytochemical studies. Paraffin block sections of kidney were stained using E11 MAb to $31-\mathrm{kD} \mathrm{H}^{+}$ATPase detected by FITClabeled goat anti-mouse IgG as follows: They were incubated sequentially for 4 min each in xylene three times, $100 \%$ ethanol two times, and 95\% ethanol two times, then dipped in distilled water three times. The sections were then incubated sequentially in Lugol's solution for 10 min, dipped in distilled water five times, $5 \% \mathrm{Na}$ thiosulfate for $5 \mathrm{~min}$, dipped once in distilled water, PBS (pH 7.4) for $8 \mathrm{~min}$, counterstained with hematoxylin for $20 \mathrm{~s}$, blocking solution ( $20 \%$ calf serum, $1 \%$ polyethylene glycol (PEG) mol wt 20,000, Na azide $5 \mathrm{mM}$ ) for $30 \mathrm{~min}$, undiluted E11 supernatant for $45 \mathrm{~min}$, PBS for $8 \mathrm{~min}$, fluorescein-labeled goat anti-mouse IgG diluted 1:50 (vol/vol) in blocking solution for $20 \mathrm{~min}, \mathrm{PBS}$ for $8 \mathrm{~min}$, and finally mounted with a fresh mixture of p-phenylene diamine $2 \mathrm{mg} / \mathrm{ml}$ in $50 \%$ glycerol (vol/vol) in PBS. The slides were viewed using an epifluorescence microscope (Olympus Optical Co., Ltd, Tokyo, Japan).

For cell counting, only cells with a distinct nucleus were included. In the collecting duct, principal cells were counted as cells with no $\mathrm{H}^{+}$ ATPase staining, and intercalated cells as those with bright staining, as validated in previous studies $(2,23,51)$. At least 500 total cells were counted in each section (20-30 tubules in cortex and medulla, each). Intercalated cells in the cortex were subclassified into six different morphologic groups: ( $a$ ) well-polarized apically stained cells (WPA-stain limited to the apical region of the cell); $(b)$ poorly polarized apically stained cells (PPA-staining accentuated in the apical region although extending beyond the nucleus to the basolateral region); $(c)$ well-polarized basolaterally stained cells (WPB-stain limited to the basolateral region of the cell); $(d)$ poorly polarized basolaterally stained cells (PPB -stain accentuated in the basolateral region of the cell but extending beyond the nucleus); (e) cells with simultaneously distinct basolateral and apical pole staining (BA); and $(f)$ Cells with diffuse homogeneous staining (D). 
In the inner half of the outer stripe of the outer medulla, the percentages of principal cells, total intercalated cells, and apically stained (A), basolaterally stained (B), and diffusely stained (D) intercalated cells were calculated. The intercalated cells showing apically polarized staining (the major pattern in this segment) were subdivided into cells with a predominantly cytoplasmic distribution (in vacuoles) of $\mathrm{H}^{+}$ATPase staining, and cells with prominent plasma membrane (rim) staining.

Statistical analysis. All values are expressed as mean \pm SEM. Student's $t$ test was used for analysis of variance. $P$ values $<0.05$ were considered to be statistically significant.

\section{Results}

Plasma and urine changes with acid and alkali loading. Five or six rats were included in each of the control, acid-loaded, and alkali-loaded groups for each time point of the study. The
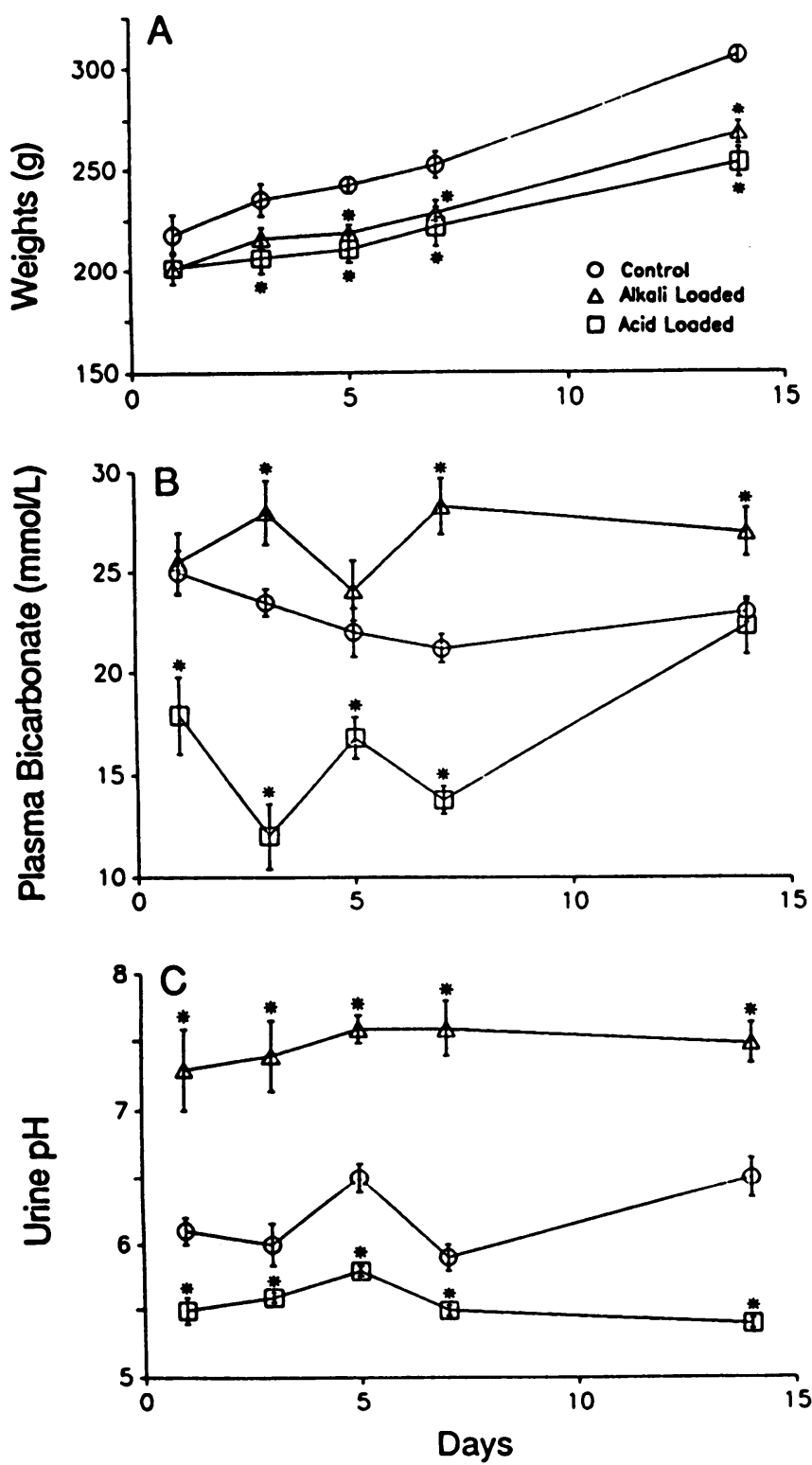

Figure 1. Changes in weight, plasma bicarbonate, and urine $\mathrm{pH}$ in (o) control, $(\Delta)$ alkali-loaded, and $(\square)$ acid-loaded rats over the 2-wk study period. Each point indicates mean \pm SEM. ${ }^{*} P<0.05$ compared to control. L, liter. weight, plasma bicarbonate, and urine $\mathrm{pH}$ levels are shown in Fig. 1. Acid loading produced an immediate fall in urine $\mathrm{pH}$, and alkali loading a rise in urine $\mathrm{pH}$, that persisted for $2 \mathrm{wk}$. The urine $\mathrm{pH}$ values were significantly different in the three groups throughout the study period. Acid loading produced a progressive drop in plasma bicarbonate over the 1st wk, although the plasma bicarbonate was restored to normal by the end of $2 \mathrm{wk}$. In the alkali-loaded animals, plasma bicarbonate levels were significantly elevated on days 3,7 , and 14 . The changes in urine $\mathrm{pH}$ and plasma bicarbonate verify that renal adaptation to acid and alkali loading ensued.

Effect of acid and alkali loading on $\mathrm{H}^{+}$ATPase 31-kD subunit protein levels. To validate the dot immunobinding assay, we showed that over $90 \%$ of ${ }^{125} \mathrm{I}$-labeled $\mathrm{H}^{+}$ATPase $31-\mathrm{kD}$ subunit, purified by electroelution, bound to the nitrocellulose membrane when mixed with different quantities of kidney microsomes in the range of 1-10 $\mu \mathrm{g}$, well within the range used for the assays, demonstrating that recovery of the subunit protein on the membrane was quantitative. There was a linear relationship between the amount of protein applied either as microsomes ranging between 5 and $12 \mu \mathrm{g}$ of protein $(r=0.94)$, or as affinity-purified $31-\mathrm{kD} \mathrm{H}^{+}$ATPase ranging between 500 and $2,000 \mathrm{ng}$ of protein $(r=0.97)$, and the densitometric measurement.

The assay was used to measure the relative quantity of $\mathrm{H}^{+}$ ATPase $31-\mathrm{kD}$ subunit protein in both cortical and medullary samples from the three groups of rats (Fig. 2). There was no

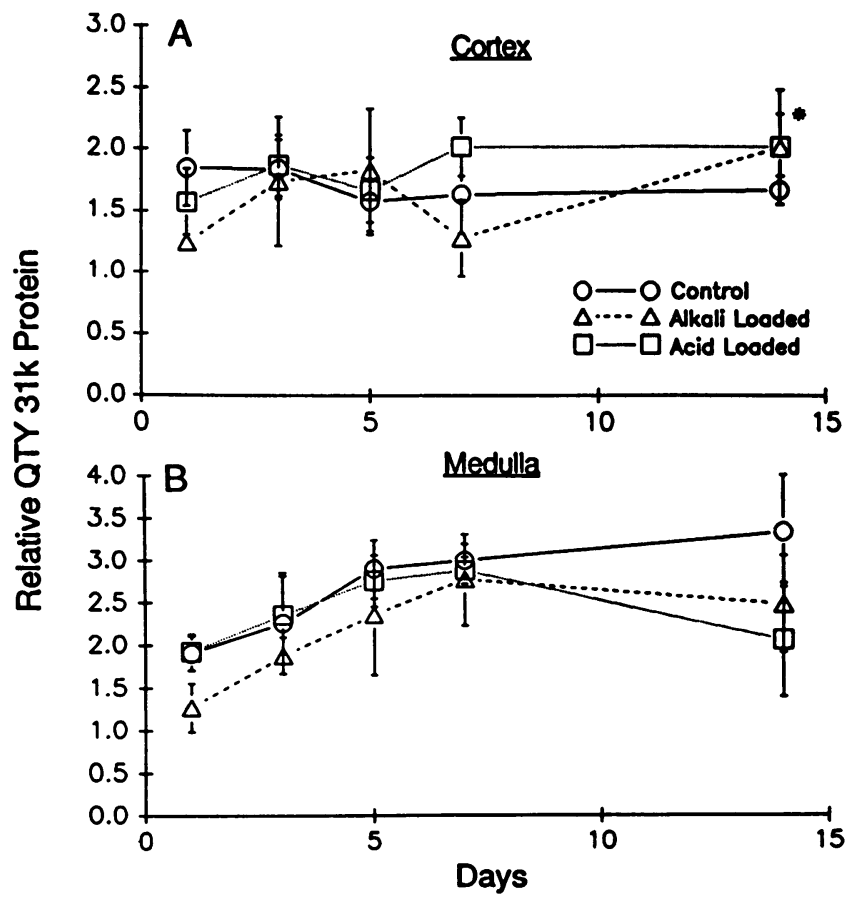

Figure 2. Changes in $\mathrm{H}^{+}$ATPase $31-\mathrm{kD}$ subunit protein with time in microsomes from ( $(0)$ control, $(\Delta)$ alkali-loaded, and ( $\square$ ) acid-loaded rats. Microsomes in $A$ were from cortex and in $B$ were from medulla. Measurements were performed using a dot immunobinding assay using procedures described in Methods. The $y$-axis (relative quantity of $31-\mathrm{kD}$ protein) represents the ratio of values from experimental microsome samples over a standard sample of purified $31-\mathrm{kD}$ subunit, quantified by densitometry. Each point indicates mean \pm SEM ${ }^{*} P<0.05$ for day 14 alkali-loaded rat cortex compared to control. 
significant change in $\mathrm{H}^{+}$ATPase content detected at any time point, except for the cortices of day 14 alkali-loaded animals vs. controls (Fig. 2).

Effect of acid loading and alkali loading on $\mathrm{H}^{+}$ATPase 31-kD subunit mRNA levels. To validate the assay for relative quantitation of $31-\mathrm{kD}$ subunit mRNA, we demonstrated a linear relationship between the amount of RNA applied in each well of the dot or slot blot, and the densitometry values obtained from autoradiograms of the membranes $(r=0.99$ in the range of $0.5-10 \mu \mathrm{g}$ of total RNA per dot, and $r=0.97$ in the range of $0.5-3 \mu \mathrm{g}$ per slot).

In RNA prepared from renal cortex of control, acid-loaded, and alkali-loaded rats, the ratios of $31-\mathrm{kD} \mathrm{H}^{+}$ATPase mRNA over $\beta$-actin mRNA showed no change at different time points over the two-week study period (Fig. $3 A$ ). In the medullary RNA samples (Fig. $3 B$ ), the $31-\mathrm{kD} / \beta$-actin mRNA ratios from alkali-loaded animals were slightly higher (1.5-2-fold) than the controls, reaching significance only on days 3 and $7.31-\mathrm{kD} / \beta$ actin mRNA ratios for acid-loaded rats were slightly higher than controls, but with statistical significance only on day 3 . The medullary $31-\mathrm{kD} / \beta$-actin mRNA ratio in each group did not change substantially over the 2-wk study period (Fig. 3 B). The results were nearly identical when a rat $18 \mathrm{~S}$ ribosomal cDNA probe was used as an internal control instead of the $\beta$-actin probe (not shown).

Effect of acid and alkali loading on the immunocytochemical distribution of $\mathrm{H}^{+}$ATPase in cortex and medulla. In prior studies, we used polyclonal antibodies, affinity purified to three subunits of the kidney vacuolar $\mathrm{H}^{+}$ATPase, to examine the immunocytochemical distribution of the enzyme in normal rat

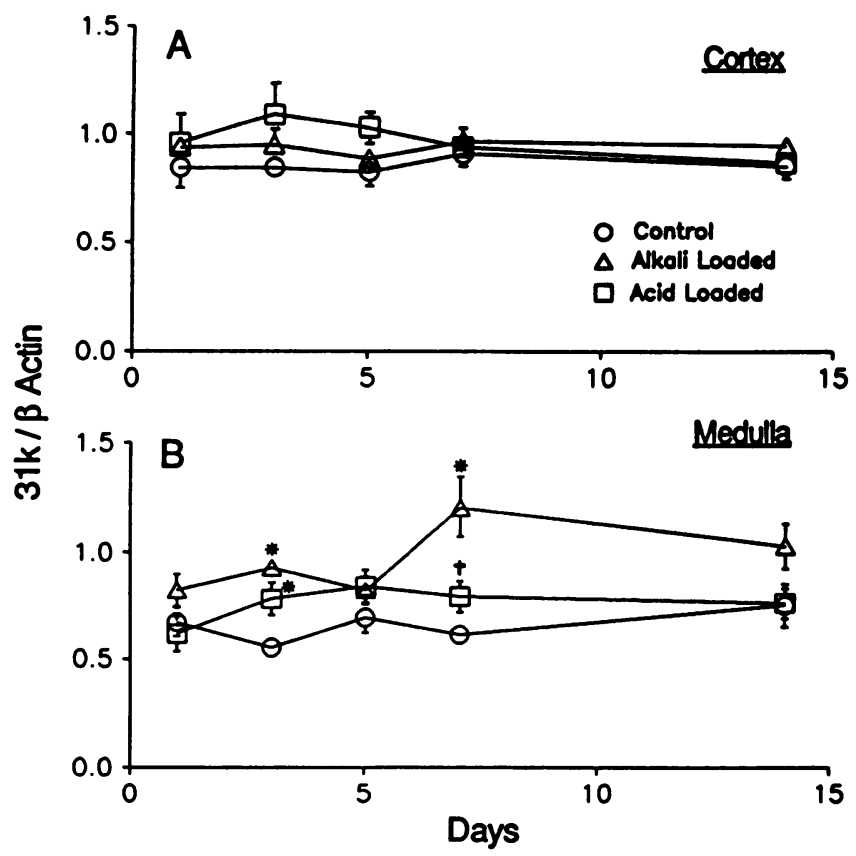

Figure 3. Ratios of $31-\mathrm{kD} \mathrm{H}^{+}$ATPase mRNA over $\beta$-actin mRNA from $(A)$ cortex and $(B)$ medulla in $(0)$ control, $(\Delta)$ alkali-loaded, or () acid-loaded rats. Assays were performed as described in Methods. The $\mathrm{y}$-axis represents the ratio of values from the $31-\mathrm{kD}$ probe over values from the actin probe, quantified by densitometry. Each point indicates mean \pm SEM. ${ }^{*} P<0.05$ compared to control; ${ }^{\dagger} P<0.05$ compared to alkali-loaded. kidney $(2,23)$. Identical staining patterns were observed with antibodies to the 70-, 56-, and $31-\mathrm{kD}$ subunits of the enzyme (2). $\mathrm{H}^{+}$ATPase staining was observed in the invaginations at the base of the microvilli (subvillar invaginations) in all proximal tubule subsegments, and staining of the microvilli was found in $S_{1}$ and $S_{2}$. Moderate staining was found in the apical pole of the thick ascending limb cells, and in the apical region of the distal convoluted tubule cells. Heavy staining of the intercalated cells was observed, and several morphologic subtypes of intercalated cells were described $(2,23,51)$. For immunocytochemistry in the present study, we used monoclonal antibody E11 (49). The immunocytochemical staining pattern for $\mathrm{H}^{+}$ATPase in the normal kidney obtained with E11 antibody was indistinguishable from that obtained with the polyclonal antibodies. Representative sections of cortex and medulla stained with the antibody are shown in Fig. 4.

The intensity of $\mathrm{H}^{+}$ATPase staining of brush border in $\mathrm{S}_{1}$ and $S_{2}$, the subvillar invaginations in $S_{3}$, and the punctate apical staining of the thick ascending limb were the same in the control, acid-loaded, and alkali-loaded rats. The distal convoluted tubules in the vicinity of the glomeruli stained qualitatively more intensely in the acid-loaded rats than in controls. The most evident change was in the distribution of $\mathrm{H}^{+}$ATPase staining within the cortical and medullary intercalated cells (discussed below). Intercalated cells comprised $44 \pm 1.5 \%$ of the cells in the cortical collecting tubules and $45.7 \pm 0.65 \%$ of the cells in the medullary collecting tubules in all three groups and did not change over the 2-wk experimental period.

We observed rapid and striking adaptational changes in the immunocytochemical distribution of $\mathrm{H}^{+}$ATPase in inner stripe. In the acid-loaded rats, the majority of cells showed a nearly complete loss of vesicular cytoplasmic $\mathrm{H}^{+}$ATPase staining, with all of the label appearing on the plasma membrane (Fig. 5), a pattern we refer to as "rim" staining. In the inner stripe, $63 \%$ of the intercalated cells from acid-loaded animals showed rim-type staining on day 1 (Fig. $6 \mathrm{~B}$ ), a large increase from the $7 \%$ and $32.5 \%$ rim cells in control and alkali-loaded animals, respectively $(P \leq 0.01)$. The percentage of rim cells in the acid-loaded rats continued to increase to $89 \%$ of the intercalated cells over the ensuing two weeks (Fig. 6 B, Table I). The percentage of rim cells in the alkali loaded animals was significantly higher than the control value at day 1 , but decreased to $15-20 \%$ for all subsequent time points, values not significantly different from the $3-12 \%$ in controls.

The response of the outer stripe of the outer medulla to acid loading was similar to that of the inner stripe, but with a slower time course. The percentage of outer stripe intercalated cells with rim $\mathrm{H}^{+}$ATPase staining (Fig. $6 \mathrm{~A}$ and Table I) was $25 \%$ on day 1 in the acid loaded rats compared to $7.7 \%$ in the alkaliloaded and $2 \%$ in the control rats $(P \leq 0.01)$, but still well below the day 1 value of $63 \%$ in the inner stripe (Fig. 6 B). Outer stripe rim cells in the acid-loaded rats increased nearly linearly over the 2 -wk period to $68 \%$, with no change ( $7 \%$ and $4 \%$, respectively) in the number of rim cells in the alkali-loaded and control rats.

In the cortical collecting duct, we identified six different morphologic subtypes of intercalated cells, illustrated in Fig. 7. We consistently noted a population of cells exhibiting a bipolar (B-A) staining pattern, which were not noted in this abundance in previous immunocytochemical studies $(2,23,51)$. In the normal rats, the percent for each subtype of intercalated cell 

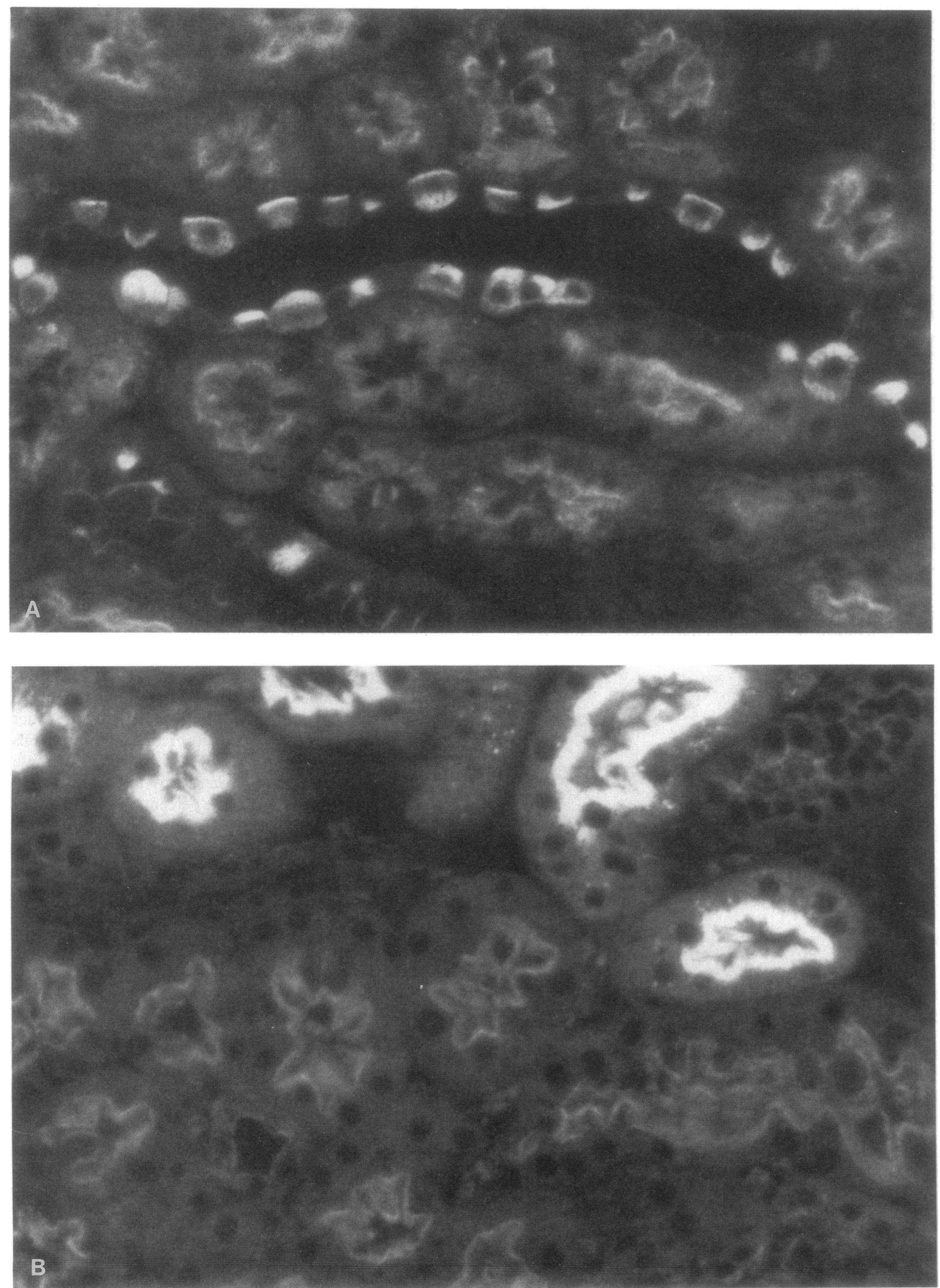

130 Bastani et al. 

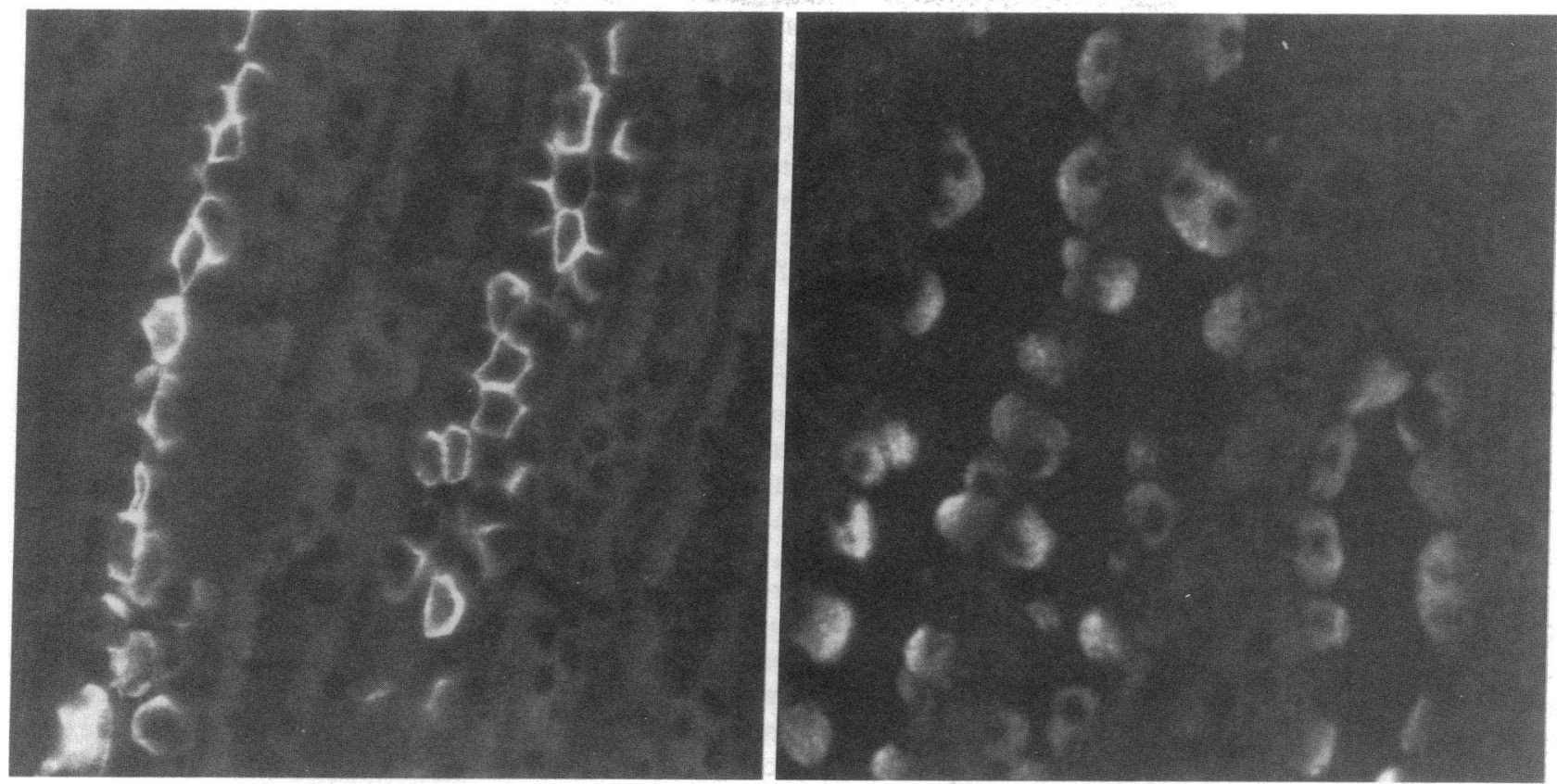

Figure 5. Different patterns of $\mathrm{H}^{+}$ATPase staining in intercalated cells of medullary collecting tubules. (Left) Rim: staining of plasma membrane with no cytoplasmic staining. Kidney shown is from an acid-loaded rat. (Right) Cytoplasmic: staining in cytoplasmic vesicles with no detectable plasma membrane staining. Kidney shown is from an alkali-loaded rat.

observed in the cortical collecting tubule was: WPA $(41 \pm 2.3 \%)$, PPA $(25 \pm 1.9 \%)$, WPB $(2 \pm 0.3 \%)$, PPB $(17 \pm 1.1 \%)$, B-A $(5 \pm 0.5 \%)$, and $\mathrm{D}(10 \pm 1.0 \%)$.

In the cortical collecting tubule of acid-loaded rats, the most obvious change was a steady increase in the number of the WPA cells from $44.7 \%$ to $70 \%$ over the 2 -wk period $(P$ $<0.01)$. This was accompanied by declines in the number of PPA cells from $32 \%$ to $14 \%$, D cells from $11 \%$ to $4.8 \%$, and B-A cells from $3.8 \%$ to $1.8 \%$. The percentages of both PPA and D cells were the same as control values on days 1 and 3 , and thereafter decreased as the number of WPA cells increased (Table I). The percentages of PPB, B-A, and WPB intercalated cells were lower at all time points in the acid-loaded rats as compared to controls, with statistical significance as indicated in Table I.

In the alkali-loaded animals, an increase in WPA cells, with a concomitant decrease in PPA cells, was observed on day 1 , but thereafter their percentages remained unchanged from control rats (Table I). At several time points, the percentage of B-A cells was significantly higher in the alkali-loaded rats (range $6.5-11 \%$, mean $9 \pm 0.7 \%$ ) when compared with control rats (range $3-6 \%$, mean $5 \pm 0.5 \%$ ). The percentage of WPB cells was always higher in the alkali-loaded than in control animals, but never reached statistical significance (Table I).

\section{Discussion}

We examined the role of the principal distal proton transporter, the renal vacuolar $\mathrm{H}^{+}$ATPase, in the adaptive response by measuring the amount of the protein, its intracellular distribution, and the levels of mRNA coding for the protein in different parts of the kidneys of rats subjected to chronic dietary acid or alkali loads. Our experiments reveal that renal adaptation in rats is not associated with detectable changes in the levels either of proton ATPase mRNA or protein in cortex or medulla. The major demonstrable adaptational change was in the intracellular distribution of $\mathrm{H}^{+}$ATPase in the intercalated cells. Some caution must be maintained in interpreting the results. Since vacuolar $\mathrm{H}^{+}$ATPases are present in all cell types throughout the kidney, it is possible that a constant level of the protein and its message arising from segments other than the collecting duct masked changes occurring specifically in intercalated cells. However, the intensity of immunocytochemical staining for $\mathrm{H}^{+}$ATPase in intercalated cells did not appear to change, which suggests that major changes in $\mathrm{H}^{+}$ATPase content did not occur. Our results also do not exclude the possibility that kinetic regulation of proton pump enzymatic activity may have a role in adaptation. Although acid and alkali loading were the physiologic stimuli examined in the study, the

Figure 4. Paraffin sections of rat kidney stained with anti- $\mathrm{H}^{+}$ATPase MAb E11. (A) Outer cortex showing cross-sections of proximal tubules $\left(\mathrm{S}_{1}\right.$ or $\mathrm{S}_{2}$ segments) with staining of both the brush border microvilli and the subvillar invaginations. A longitudinal section of a cortical collecting tubule is shown in the center. The cortical collecting tubule contains cells with no $\mathrm{H}^{+}$ATPase staining (principal cells) and intercalated cells with various patterns of $\mathrm{H}^{+}$ATPase staining as described in the text. $(B)$ Junction of the cortex and the outer stripe of the outer medulla. Upper field shows four proximal tubules $\left(\mathrm{S}_{1}\right.$ or $\mathrm{S}_{2}$ segments) with bright brush border staining for $\mathrm{H}^{+}$ATPase. Lower field shows several proximal tubules ( $S_{3}$-pars recta) in the outer medulla outer with moderate staining of subvillar invaginations. 

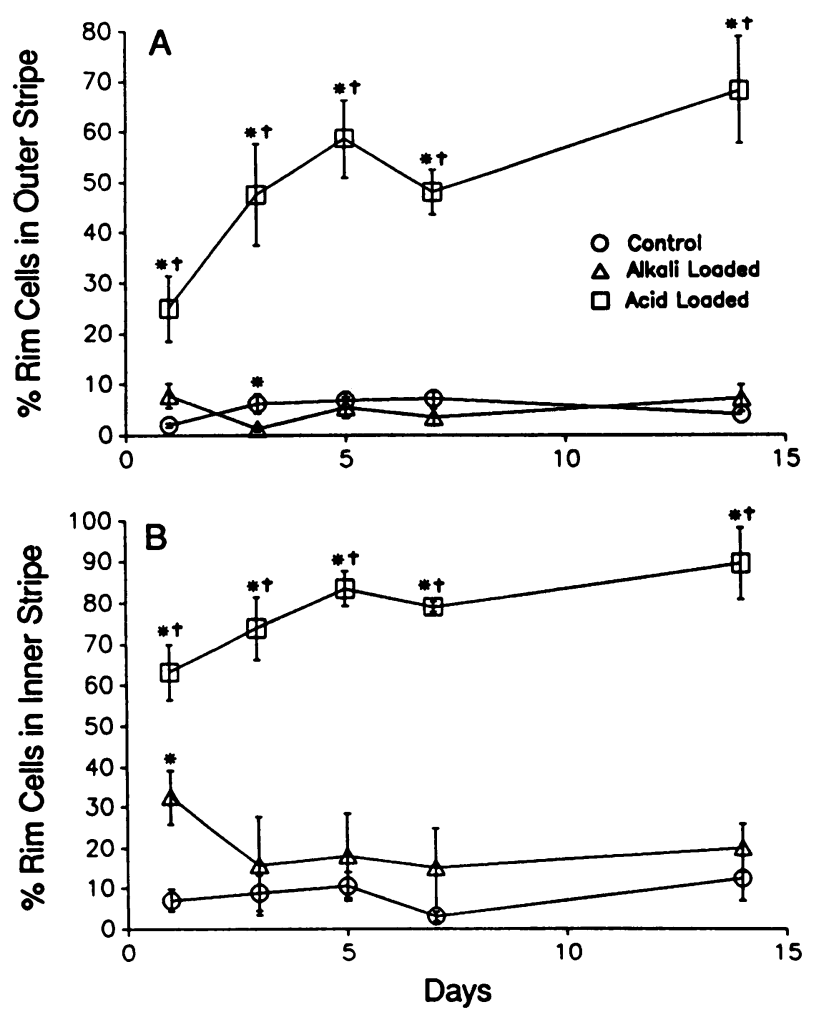

Figure 6. Changes with time in the percent of "rim" cells in $(A)$ outer stripe and $(B)$ inner stripe, of $(0)$ control, $(\Delta)$ alkali-loaded, or $(\square)$ acid-loaded animals. ${ }^{*} P<0.05$ compared to control; ${ }^{\dagger} P<0.05$ compared to alkali-loaded animals. principal variable inducing the observed changes in the kidney is still unknown. For example, the animals in the acid-loaded group probably received more chloride, and the alkali-loaded group more sodium, than controls. Levels of aldosterone and other hormones that could affect acidification were also not measured. However, the goal of the study was to examine the renal response to acid and alkali loading rather than the nature of the physiologic signal.

We used a newly developed monoclonal antibody to the kidney vacuolar $\mathrm{H}^{+}$ATPase which has increased sensitivity, with identical or better specificity, compared to the affinitypurified polyclonal antibodies which we previously used to stain rat kidney $(2,23)$. In several segments of the nephron there was no discernible change in $\mathrm{H}^{+}$ATPase staining under the experimental conditions used. In the proximal tubule, the $S_{1}$ and $S_{2}$ segments showed heavy brush border staining, and all proximal segments showed staining of the subvillar basilar invaginations similar to our previous results (2). The apical punctate staining in the thick ascending limbs of the loop of Henle was also the same in the three groups and appeared as previously described (2). The intercalated cells in both the cortical and medullary collecting tubules constituted about $44 \%$ of the cells in all three groups of rats. This value agrees with those from previous reports in rat $(28,51-56)$ or rabbit $(57-59)$ in which morphologic criteria, carbonic anhydrase or succinate dehydrogenase histochemistry, or anti-band 3 immunocytochemistry were employed to identify intercalated cells. We found that many of the $\mathrm{H}^{+}$ATPase-stained intercalated cells did not fall unequivocally into any of the three morphologic categories (apical, basolateral, and diffuse) used previously to
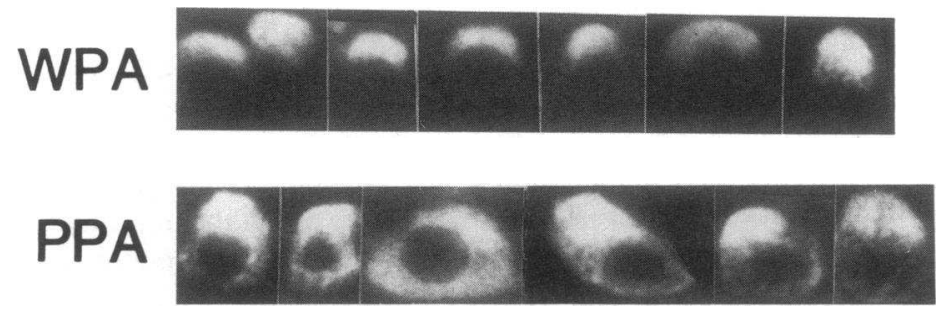

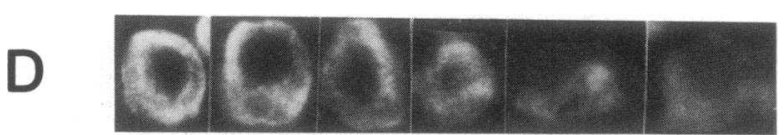

B-A

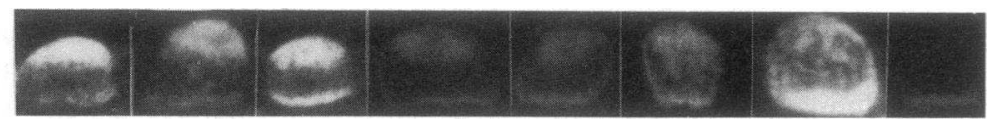

PPB

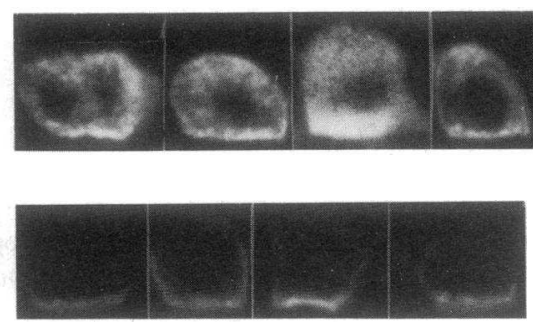

Figure 7. Different patterns of $\mathrm{H}^{+}$ATPase staining in intercalated cells of cortical collecting tubules. WPA: staining limited to the apical pole. PPA: accentuated staining of the apical pole extending beyond the nucleus. D: diffuse staining throughout the cell. BA: accentuated staining at both the apical and basolateral poles. PPB: accentuated staining of the basolateral pole extending beyond the nucleus. WPB: staining limited to the basolateral membrane. 
Table I. Percentage of Different Types of Intercalated Cells at Indicated Time Points in Cortical Collecting Tubules and Outer Medullary Collecting Tubule Outer Stripes and Inner Stripes from Control, Alkali-loaded, and Acid-loaded Rats over the 2-wk Study Period

\begin{tabular}{|c|c|c|c|c|c|c|c|c|c|c|c|c|c|c|c|}
\hline & \multicolumn{3}{|c|}{ Day 1} & \multicolumn{3}{|c|}{ Day 3} & \multicolumn{3}{|c|}{ Day 5} & \multicolumn{3}{|c|}{ Day 7} & \multicolumn{3}{|c|}{ Day 14} \\
\hline & C & Al & Ac & C & Al & Ac & C & Al & Ac & C & Al & Ac & C & Al & Ac \\
\hline \multicolumn{16}{|c|}{ Cortical collecting tubules } \\
\hline \% WPB & 2.0 & 2.0 & 0.7 & 1.2 & 3.6 & $0.1^{*}$ & 2.7 & 3.2 & $0.2^{* \pm}$ & 1.3 & 2.4 & $0.7^{\ddagger}$ & 1.7 & 3.5 & $0.5^{* \pm}$ \\
\hline $\mathrm{SE}$ & 0.7 & 0.3 & 0.2 & 0.2 & 1.6 & 0.1 & 0.6 & 0.5 & 0.1 & 0.4 & 0.4 & 0.2 & 0.3 & 0.8 & 0.2 \\
\hline$\%$ PPB & 20.5 & $11.0^{*}$ & $9.1^{*}$ & 15.0 & 20.0 & $5.9^{* \neq}$ & 18.0 & 13.6 & $6.2^{*}$ & 14.5 & $19.2^{*}$ & $8.3^{* \pm}$ & 19.9 & 16.5 & $9.0^{* \neq}$ \\
\hline SE & 1.5 & 1.6 & 0.9 & 2.1 & 2.1 & 1.0 & 1.9 & 3.2 & 1.0 & 1.8 & 0.6 & 1.5 & 2.3 & 1.2 & 1.3 \\
\hline$\% \mathbf{B A}$ & 6.0 & $11.0^{*}$ & $3.8^{\ddagger}$ & 3.1 & 6.5 & $3.5^{\ddagger}$ & 4.2 & $10.2^{*}$ & $2.2^{\ddagger}$ & 5.6 & 8.5 & $2.2^{\ddagger}$ & 5.8 & $9.4^{*}$ & $1.8^{* \pm}$ \\
\hline SE & 1.5 & 1.0 & 0.7 & 1.3 & 0.9 & 0.7 & 0.8 & 1.8 & 0.7 & 1.2 & 1.6 & 1.2 & 1.0 & 1.2 & 1.0 \\
\hline$\% \mathrm{D}$ & 8.8 & 7.1 & 11.0 & 14.0 & $9.0^{*}$ & 10.2 & 9.5 & 8.8 & $5.3^{* \neq}$ & 8.6 & 8.4 & $5.8^{*}$ & 9.8 & 8.0 & $4.8^{*}$ \\
\hline SE & 1.3 & 0.9 & 1.5 & 1.2 & 1.4 & 1.9 & 1.0 & 0.9 & 0.8 & 0.6 & 1.6 & 0.5 & 1.6 & 1.3 & 0.6 \\
\hline$\%$ PPA & 25.0 & $15.9^{*}$ & 30.7 & 32.0 & 24.2 & 32.6 & 21.9 & 24.0 & 32.0 & 22.2 & 20.8 & 24.5 & 19.2 & 23.6 & 14.0 \\
\hline $\mathrm{SE}$ & 1.9 & 1.9 & 6.4 & 3.1 & 8.6 & 4.3 & 5.7 & 4.0 & 3.8 & 5.2 & 4.1 & 3.6 & 4.8 & 3.6 & 4.5 \\
\hline$\%$ WPA & 37.7 & $53.0^{*}$ & 44.7 & 34.7 & 36.7 & $47.7^{*}$ & 43.7 & 40.2 & $54.1^{\ddagger}$ & 47.8 & 40.7 & $58.5^{\ddagger}$ & 43.6 & 39.0 & $69.9^{* \neq}$ \\
\hline $\mathrm{SE}$ & 3.6 & 3.4 & 4.5 & 1.4 & 8.2 & 2.8 & 6.3 & 4.1 & 2.7 & 4.4 & 4.6 & 2.6 & 5.9 & 4.6 & 5.2 \\
\hline \multicolumn{16}{|c|}{$\begin{array}{l}\text { Outer medullary collecting } \\
\text { tubule outer stripes }\end{array}$} \\
\hline \% rim & 2.0 & 7.7 & $25.0^{* \neq}$ & 6.0 & $1.2^{*}$ & $47.5^{* \neq}$ & 6.7 & 5.3 & $58.6^{* \pm}$ & 7.0 & 3.4 & $48.0^{* \neq}$ & 4.0 & 7.0 & $68.0^{* \pm}$ \\
\hline $\mathrm{SE}$ & 0.4 & 2.4 & 6.5 & 1.9 & 0.5 & 10.0 & 1.6 & 2.0 & 7.7 & 1.4 & 1.6 & 4.5 & 0.0 & 2.6 & 10.6 \\
\hline \multicolumn{16}{|c|}{$\begin{array}{l}\text { Outer medullary collecting } \\
\text { tubule inner stripes }\end{array}$} \\
\hline$\%$ rim & 7.0 & $32.5^{*}$ & $63.2^{* *}$ & 8.8 & 15.6 & $73.8^{* \ddagger}$ & 10.5 & 18.0 & $83.4^{* \neq}$ & 3.0 & 15.0 & $79.0^{* \neq}$ & 12.4 & 20.0 & $89.3^{* \neq}$ \\
\hline SE & 2.7 & 6.7 & 6.8 & 4.3 & 12.2 & 7.6 & 3.5 & 10.5 & 4.2 & 1.2 & 9.9 & 1.4 & 5.5 & 6.1 & 8.7 \\
\hline
\end{tabular}

Abbreviations used in this table: Ac, acid-loaded rats; Al, alkali-loaded rats; $\mathrm{C}$, control rats. ${ }^{*} P<0.05$, vs. control. ${ }^{\ddagger} P<0.05$, Ac vs. Al.

enumerate cells (23). We identified six different immunocytochemical subtypes of cortical intercalated cells, including newly defined PPA, PPB, and B-A cells (Fig. 7), and a newly defined "rim" cell in medulla (Fig. 5). We analyzed the changes in prevalence with time for each of the subtypes separately.

A novel finding in the study was the consistent detection of cells with accentuated apical and basolateral staining (B-A cells), comprising $5 \%$ of the cortical intercalated cells in controls. Inasmuch as the nucleus was clearly visible in all cross sections of these cells, it is unlikely that this staining pattern was an artifact of the angle of sectioning. The detection of these cells in controls and alkali-loaded animals suggests that they are not engaged in the process of interconversion from "type B" to "type A" cells in response to acid loading $(39,41)$, but represent a population of true bipolar cells. Shifts in the distribution of $\mathrm{H}^{+}$ATPase in a bipolar cell could produce a cell with accentuated staining at either the apical or basolateral pole. For this reason, we counted the poorly polarized cells separately in order to avoid assigning them arbitrarily as a single physiologic subgroup of A or B cells (53).

Acid loading induced conspicuous changes in the distribution of $\mathrm{H}^{+}$ATPase throughout the collecting duct. The most obvious changes occurred in the inner and outer stripe of the outer medulla. In both segments, chronic acid loading induced the appearance of "rim" cells, with $\mathrm{H}^{+}$ATPase staining localized primarily in the apical plasma membrane. The time course of the response differed significantly in the two segments. The inner stripe had the most striking response, with rim cells increasing from $7 \%$ to $63 \%$ after only $1 \mathrm{~d}$, and increas- ing to $89 \%$ of the intercalated cells over the ensuing 2 wk. The outer stripe rim cells increased from $2 \%$ to $25 \%$ of the intercalated cells after $1 \mathrm{~d}$ of acid loading, and rose to $68 \%$ of the intercalated cells at 2 wk. McKinney and Davidson $(31,60)$ also noted significant physiologic differences in $\mathrm{H}^{+}$secretion between the inner and outer stripe. They found that the two segments varied in the susceptibility to carbonic anhydrase inhibitors and the response to stimulation with $\mathrm{CO}_{2}$. Our observation that net transfer of $\mathrm{H}^{+}$ATPase to the apical membrane occurs with different time courses in two segments, and takes place slowly over $2 \mathrm{wk}$ in the outer stripe, suggests that this response is not a "servo" mechanism for regulating intracellular $\mathrm{pH}$ as previous studies suggested $(61,62)$. Recent investigations $(63,64)$ have established that basolateral $\mathrm{Na}^{+} / \mathrm{H}^{+}$exchange and $\mathrm{Cl}^{-}$/base exchange are major mechanisms for regulation of intracellular $\mathrm{pH}$ in intercalated cells. Conceivably, the change in intercalated cell relative polarization may be hormonally mediated (65-67).

Acid loading produced pronounced changes in the distribution of $\mathrm{H}^{+}$ATPase in the cortex as well. The percentage of WPA intercalated cells increased from $45 \%$ to $70 \%$ over $2 \mathrm{wk}$, with an early decline in the numbers of WPB and PPB cells, and a late decrease in the percent of PPA and BA cells.

In the inner medulla (papilla), intercalated cells, present in the initial one-third $(2,68,69)$ developed accentuated rim staining in the acid-loaded rats. In the inner stripe and papilla of rats acid-loaded for $14 \mathrm{~d}$, expanded intercalated cells showing marked rim staining protruded obtrusively, abutting each other and nearly occluding the lumen. As described in previous 
studies $(2,68,69)$, we found that the innermost part of the inner medulla was devoid of intercalated cells. We did not detect any plasma membrane $\mathrm{H}^{+}$ATPase staining of the papillary principal cells in control or acid-loaded rats. Wall et al. (36) observed that $\mathrm{H}^{+}$secretion in this segment increased after acid loading, and suggested that it may employ an $\mathrm{H}^{+}-\mathrm{K}^{+}$ATPase. Evidence for a renal $\mathrm{H}^{+}-\mathrm{K}^{+}$ATPase in cortical collecting tubule has been described in potassium depletion (70), and may mediate active potassium reabsorption.

The effects of chronic acid loading on $\mathrm{H}^{+}$ATPase staining in other nephron segments were difficult to quantitate. Distal convoluted tubular cells had apical plasma membrane $\mathrm{H}^{+}$ATPase staining in all three groups of rats, but the staining appeared brighter in the acid-loaded rats. There was no apparent change in the loop of Henle.

Chronic alkali loading induced less obvious but significant changes in the distribution of $\mathrm{H}^{+}$ATPase. In the cortical collecting tubule, alkali loading induced significant increases in PPB and B-A cells at several time points (Table I). In the medulla, rim cells were $15-32.5 \%$ and $1-8 \%$, respectively, of the intercalated cells in the inner and outer stripe, and their numbers did not change substantively with alkali loading except on day 1 , when an increase was observed.

These results demonstrate that acid loading shifts the distribution of $\mathrm{H}^{+}$ATPase in intercalated cells toward the apical pole and away from the basolateral pole in the cortical collecting duct, and to the apical plasma membrane in the medullary collecting duct. Alkali loading, inducing less apparent changes, decreases the relative polarization of intercalated cells by increasing the number of subtypes with cytoplasmic staining, and increasing subtypes such as PPB and B-A cells, suggesting that it shifts the proton ATPase away from the apical pole and toward the basolateral pole.

To explain our results, we propose a mechanism for renal adaptation (Fig. 8). In this model, the medullary collecting duct has intercalated cells with $\mathrm{H}^{+}$ATPase which recycles between cytoplasmic vesicles and plasma membrane only at the apical pole (apical cells). Acid loading induces an increase in the relative polarization of these cells with movement of the $\mathrm{H}^{+}$ATPase to the apical plasma membrane. Alkali loading causes the $\mathrm{H}^{+}$ATPase to shift to intracellular vesicles. In the cortical collecting duct two functional subtypes of intercalated cell are present, an apical cell, and a bipolar cell. Acid and alkali loading induces changes in the apical cell of the cortex similar, in magnitude and time course, to those occurring in the apical cell of the outer stripe. The bipolar cell differs from the apical cell in its ability to recycle $\mathrm{H}^{+}$ATPase between cytoplasmic vesicles and both the basolateral and apical plasma membrane. Acid loading induces the bipolar cell to lose its relative polarization at the basolateral pole, giving it the appearance of a diffuse or poorly polarized apical cell. Alkali loading produces opposite effects on the bipolar cell, increasing the relative polarization at the basolateral pole, and decreasing polarization to the apical pole, giving it the appearance of either a diffuse, bipolar, or PPB cell (Fig. 8).

This model agrees with the observations of Madsen and Tisher (38) who found morphologic evidence suggesting that fusion of "studded" tubulovesicular membranes with the apical membrane occurred in the medullary intercalated cells of acid-loaded rats (38). The "studs" have been identified as the cytoplasmic domain of the vacuolar $\mathrm{H}^{+}$ATPase in these cells (21). The proposed model would account for the detection of a stable population of bipolar cells. This would concur with the observations of Ridderstrale et al. (59), who found that many of the intercalated cells in rabbit cortical collecting tubule had rod-shaped particles in both the apical and basolateral membranes. The model would also explain the changes in the distribution of cortical intercalated cell subtypes shown in Table I.

Our proposed model could explain the apparent interconversion of proton and bicarbonate secreting cells proposed by Schwartz and colleagues $(39,41)$. Using 6-carboxyfluorescein diacetate as a probe, they identified only $25 \%$ of the cells in either cortical or medullary collecting duct as intercalated cells. This value is substantially lower than our value of $44 \%$.

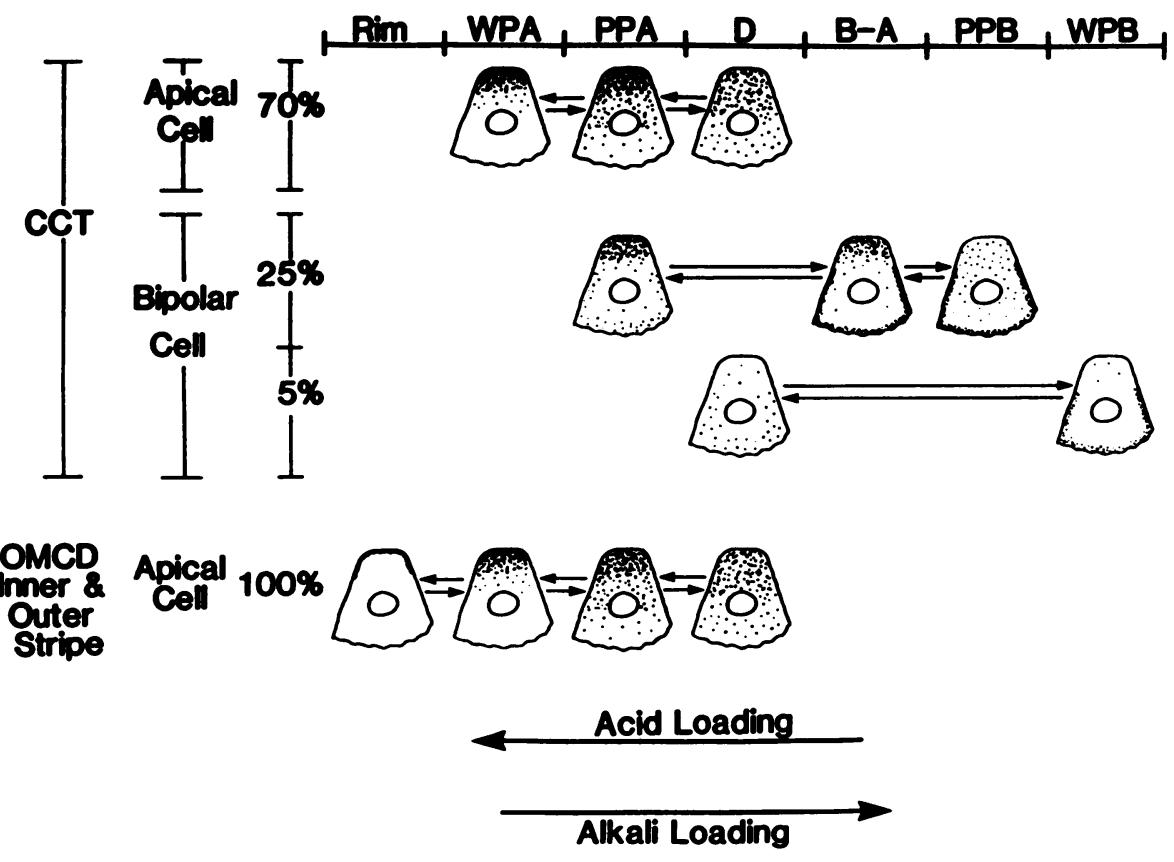

Figure 8. Illustration of postulated mechanism underlying adaptation of intercalated cells in cortical collecting tubules $(C C T)$ and outer medullary collecting duct $(O M C D)$ to acid or alkali loads as detailed in the text. 
Schwartz and colleagues (39-41) also found that only 5-10\% of the intercalated cells displayed apical endocytosis, which they used as the criterion for an acid-secreting cell. This value is well below the $29-66 \%$ intercalated cells proposed as proton-secreting on the basis of basolateral staining with anti-anion transporter (band 3 ) antibodies $(51,54,56,57)$ or the luminal appearance of cells by transmission or scanning electron microscopy $(38,52,53,58)$ in rat and rabbit, and well below our finding of $65 \%$ of cortical intercalated cells with enhanced apical $\mathrm{H}^{+}$ATPase staining. The simplest explanation is that acid loading activates "dormant," nonendocytic intercalated cells, inducing them to exhibit apical endocytosis. Such activation could conceivably occur either exclusively in "apical" cells or also in "bipolar" cells. Activation of apical endocytosis would be compatible with the shifts in $\mathrm{H}^{+}$ATPase toward the apical membrane which we observed in acid loading, as increases in membrane insertion and recycling are known to occur in intercalated cells and their reptilian analogues in response to $\mathrm{CO}_{2}$ (71-74). Our model does not require a global reorganization of cell structure or polarity.

The changes we observed in the cortical collecting tubule are consistent with the physiologic studies of this segment in the rabbit showing loss of net bicarbonate secretion in acidloaded animals $(24,26,32)$. These physiologic studies introduced the concept that distal acid-base adaptation occurred predominantly in the cortex. Studies have subsequently demonstrated physiologic adaptation in the medullary thick ascending limb (75) and in the inner medulla $(33,35,36)$. Our study also shows large shifts in the distribution of $\mathrm{H}^{+}$ATPase in the outer and inner stripe, suggesting, like the investigation of Madsen and Tisher (38), that these segments have a major role in renal acid-base adaptation. However, physiologic modulation of proton secretion in response to acid or alkali loading has not been demonstrated in these segments $(24,26,31,32)$. Our results suggest that the tubule in the in vitro environment may not maintain a rate of proton secretion reflective of that operating in the intact animal. Rapid redistribution of $\mathrm{H}^{+}$ATPase has been described in proton-transporting epithelia (71-74), and perhaps the process of removal and mounting of tubules for perfusion allows proton pump redistribution to occur. Clearly, techniques for studying medullary collecting duct proton transport and $\mathrm{H}^{+}$ATPase immunocytochemistry in the isolated tubule will be required to resolve this issue.

In conclusion, we have shown that adaptation to acid and alkali loads in rat kidney is not due to changes in the quantity of vacuolar $\mathrm{H}^{+}$ATPase in cortex or medulla, but rather to redistribution of the enzyme in intercalated cells between the cytoplasmic vesicles and cell membrane. The magnitude and rapidity of the changes in the medulla suggest that the inner and outer stripe participate actively in acid-base adaptation, to a degree not previously appreciated. In the cortex, both apically polarized and bipolar cells respond, similarly to medullary intercalated cells, by increasing polarization toward the apical pole with acid loads, providing a unifying mechanism for acidbase adaptation.

\section{Acknowledgment}

We thank Betty Ytzaina for excellent assistance in preparing the manuscript.

During the course of this work, B. Bastani was supported by a fellowship from the National Kidney Foundation. The research was sup- ported in part by grants DK-38848 and DK-09976 from the National Institutes of Health. Dr. Gluck is a Sandoz Corporation Established Investigator of the American Heart Association.

\section{References}

1. Alpern, R. J. 1990. Cell mechanisms of proximal tubule acidification. Physiol. Rev. 70:79-114.

2. Brown, D., S. Hirsch, and S. Gluck. 1988. Localization of a proton-pumping ATPase in rat kidney. J. Clin. Invest. 82:2114-2126.

3. Simon, B. J., and G. Burckhardt. 1990. Characterization of inside-out oriented $\mathrm{H}^{+}$-ATPases in cholate-pretreated renal brush-border membrane-vesicles. J. Membr. Biol. 117:141-151.

4. Wang, Z.-Q., and S. Gluck. 1990. Isolation and properties of bovine kidney brush border vacuolar $\mathrm{H}^{+}$ATPase: a proton pump with enzymatic and structural differences from kidney microsomal $\mathrm{H}^{+}$ATPase. J. Biol. Chem. 265:2195721965.

5. Bank, N., H. S. Aynedjian, and B. F. Mutz. 1989. Proximal bicarbonate absorption independent of $\mathrm{Na}^{+}-\mathrm{H}^{+}$exchange: effect of bicarbonate load. $A m$. J. Physiol. 256:F577-F582.

6. Preisig, P. A., H. E. Ives, E. J. Cragoe, Jr., R. J. Alpern, and F. C. Rector, Jr. 1987. Role of the $\mathrm{Na}^{+} / \mathrm{H}^{+}$antiporter in rat proximal tubule bicarbonate absorption. J. Clin. Invest. 80:970-978.

7. Turrini, F., I. Sabolic, Z. Zimolo, B. Moewes, and G. Burckhardt. 1989. J. Membr. Biol. 107:1-12.

8. Cohn, D. E., S. Klahr, and M. R. Hammerman. 1983. Metabolic acidosis and parathyroidectomy increase $\mathrm{Na}^{+}-\mathrm{H}^{+}$exchange in brush border vesicles. $\mathrm{Am}$. J. Physiol. 245:F217-F222.

9. Kinsella, J., T. Cujdik, and B. Sacktor. 1984. $\mathrm{Na}^{+}-\mathrm{H}^{+}$exchange in isolated renal brush border membrane vesicles in response to metabolic acidosis. J. Biol. Chem. 259:13224-13227.

10. Kinsella, J., T. Cujdik, and B. Sacktor. 1984. $\mathrm{Na}^{+}-\mathrm{H}^{+}$exchange activity in renal brush border membrane vesicles in response to metabolic acidosis: the role of glucocorticoids. Proc. Natl. Acad. Sci. USA. 81:630-634.

11. Tsai, C. J., H. E. Ives, R. J. Alpern, V. J. Yee, D. G. Warnock, and F. C. Rector, Jr. 1984. Increased $V_{\max }$ for $\mathrm{Na}^{+} / \mathrm{H}^{+}$antiporter activity in proximal tubule brush border vesicles from rabbits with metabolic acidosis. Am. J. Physiol. 247:F339-F343.

12. Akiba, T., V. K. Rocco, and D. G. Warnock. 1987. Parallel adaptation of the rabbit cortical sodium/proton antiporter and sodium/bicarbonate cotransporter in metabolic acidosis and alkalosis. J. Clin. Invest. 80:308-315.

13. Preisig, P. A., and R. J. Alpern. 1988. Chronic metabolic acidosis causes an adaptation in apical membrane $\mathrm{Na}^{+} / \mathrm{H}^{+}$antiporter and basolateral $\mathrm{Na}\left(\mathrm{HCO}_{3}\right)_{3}$ symporter in rat proximal convoluted tubule. J. Clin. Invest. 82:1445-1453.

14. Northrup, T. E., S. Garella, E. Pertucci, and J. J. Cohen. 1988. Acidemia alone does not stimulate rat renal $\mathrm{Na}^{+}-\mathrm{H}^{+}$antiport activity. Am. J. Physiol 255:F237-F243.

15. Koeppen, B. M., and S. I. Helman. 1982. Acidification of luminal fluid by the rabbit cortical collecting tubule perfused in vitro. Am. J. Physiol. 242:F521F531.

16. Laski, M. E., and N. Kurtzman. 1983. Characterization of acidification in the cortical and medullary collecting tubule of the rabbit. J. Clin. Invest. 72:20502059.

17. Jacobson, H. R. 1984. Medullary collecting duct acidification. J. Clin. Invest. 74:2107-2114.

18. Gluck, S., S. Kelly, and Q. Al-Awqati. 1982. The proton translocating ATPase responsible for urinary acidification. J. Biol. Chem. 257:9230-9233.

19. Gluck, S., and Q. Al-Awqati. 1984. An electrogenic proton-translocating adenosine triphosphatase from bovine kidney medulla. J. Clin. Invest. 73:1704 1710 .

20. Gluck, S., and J. Caldwell. 1987. Immunoaffinity purification and characterization of vacuolar $\mathrm{H}^{+}$ATPase from bovine kidney. J. Biol. Chem. 262:1578015789.

21. Brown, D., S. Gluck, and J. Hartwig. 1987. Structure of the novel membrane-coating material in proton-secreting cells and identification as an $\mathrm{H}^{+} \mathrm{ATP}$ ase. J. Cell Biol. 105:1637-1648.

22. Gluck, S., and J. Caldwell. 1988. Proton-translocating ATPase from bovine kidney medulla: partial purification and reconstitution. Am. J. Physiol 254:F71-F79.

23. Brown, D., S. Hirsch, and S. Gluck. 1988. An $\mathrm{H}^{+}$ATPase in opposite plasma membrane domains in kidney epithelial cell subpopulations. Nature (Lond.). 331:622-624.

24. McKinney, T. D., and M. B. Burg. 1977. Bicarbonate transport by rabbit cortical collecting tubules: effect of acid and alkali loads in vivo on transport in vitro. J. Clin. Invest. 60:766-768.

25. McKinney, T. D., and M. B. Burg. 1978. Bicarbonate absorption by rabbit cortical collecting tubules in vitro. J. Clin. Invest. 61:1421-1427.

26. Lombard, W. E., J. P. Kokko, and H. R. Jacobson. 1983. Bicarbonate 
transport in cortical and outer medullary collecting tubules. Am. J. Physiol 244:F289-F291.

27. Schuster, V. L. 1985. Cyclic adenosine monophosphate stimulated bicarbonate secretion in rabbit cortical collecting tubules. J. Clin. Invest. 75:20562064.

28. Star, R. A., M. B. Burg, and M. A. Knepper. 1985. Bicarbonate secretion and chloride absorption by rabbit cortical collecting ducts. J. Clin. Invest. 76:1123-1130.

29. Atkins, J. L., and M. B. Burg. 1985. Bicarbonate transport by isolated perfused rat collecting ducts. Am. J. Physiol. 249:F485-F489.

30. Levine, D. Z., D. Vandorpe, M. Iacovitti, and V. Harrison. 1990. Luminal chloride modulates rat distal tubule bidirectional bicarbonate flux in vivo. J. Clin Invest. 85:1793-1798.

31. McKinney, T. D., and K. K. Davidson. 1987. Bicarbonate transport in collecting tubules from outer stripe of outer medulla of rabbit kidneys. Am. J. Physiol. 253:F816-F822.

32. Hamm, L. L., K. S. Hering-Smith, and V. M. Vehaskari. 1989. Control of bicarbonate transport in collecting tubules from normal and remnant kidneys. Am. J. Physiol. 256:F680-F687.

33. Bengele, H. H., J. H. Schwartz, E. R. McNamara, and E. A. Alexander. 1986. Chronic metabolic acidosis augments acidification along the inner medullary collecting duct. Am. J. Physiol. 250:F690-F694.

34. DuBose, T. D., and C. R. Caflisch. 1988. Effect of selective aldosterone deficiency on acidification in nephron segments of rat inner medulla. J. Clin. Invest. 82:1624-1632.

35. Bengele, H. H., E. R. McNamara, J. H. Schwartz, and E. A. Alexander 1988. Acidification adaptation along the inner medullary collecting duct. Am. J. Physiol. 255:F1155-F1159.

36. Wall, S. M., J. M. Sands, M. F. Flessner, H. Nonoguchi, K. R. Spring, and M. A. Knepper. 1990. Net acid transport by isolated perfused inner medullary collecting ducts. Am. J. Physiol. 258:F75-F84.

37. Richardson, R. M. A., and R. T. Kunau, Jr. 1982. Bicarbonate reabsorption in the papillary collecting duct: effect of acetazolamide. Am. J. Physiol. 255:F1155-F1159.

38. Madsen, K. M., and C. C. Tisher. 1984. Response of intercalated cells of rat outer medullary collecting duct to chronic metabolic acidosis. Lab. Invest. 51:268-276.

39. Schwartz, G. J., J. Barasch, and Q. Al-Awqati. 1985. Plasticity of functional epithelial polarity. Nature (Lond.). 318:368-371.

40. Schwartz, G. J., L. M. Satlin, and J. E. Bergmann. 1988. Fluorescen characterization of collecting duct cells: a second $\mathrm{H}^{+}$-secreting type. Am. J. Physiol. 255:F1003-F1014.

41. Satlin, L. M., and G. J. Schwartz. 1989. Cellular remodeling of HCO3-secreting cells in rabbit renal collecting duct in response to an acidic environment. J. Cell Biol. 109:1279-1288.

42. Garg, L. C., and N. Narang. 1985. Stimulation of an N-ethylmaleimidesensitive ATPase in the collecting duct segment of the rat nephron by metabolic acidosis. Can. J. Physiol. Pharmacol. 63:1291-1296.

43. Sabatini, S., M. E. Laski, and N. A. Kurtzman. 1990. NEM-sensitive ATPase activity in rat nephron: effect of metabolic acidosis and alkalosis. Am. J. Physiol. 258:F297-F304.

44. Ait-Mohamed, A. K., S. Marsy, C. Barlet, and C. Khadouri. 1986. Characterization of N-ethylmaleimide-sensitive proton pump in the rat kidney: localization along the nephron. J. Biol. Chem. 261:12526-12534.

45. Hirsch, S., A. Strauss, K. Masood, S. Lee, V. Sukhatme, and S. Gluck. 1988. Isolation and sequence of a cDNA clone encoding the 31-kDa subunit of bovine kidney vacuolar $\mathrm{H}^{+}$ATPase. Proc. Natl. Acad. Sci. USA. 85:3004-3008.

46. Kingston, R. E. 1989. Guanidinium method for total RNA preparation. In Current Protocols in Molecular Biology. F. M. Ausubel, R. Brent, R. E. Kingston, D. D. Moore, J. G. Seidman, J. A. Smith, and K. Struhl, editors. Greene Publishing Associates, New York. 4.2.1-4.2.5.

47. Selden, R. F. 1989. Analysis of RNA by Northern hybridization. In Current Protocols in Molecular Biology. F. M. Ausubel, R. Brent, R. E. Kingston, D. D. Moore, J. G. Seidman, J. A. Smith, and K. Struhl, editors. Greene Publishing Associates, New York. 4.9.1-4.9.8.

48. Gene Screen Plus: Hybridization Transfer Membrane. Booklet published by Dupont Biotechnology Systems, NEN Research Products, Boston, MA

49. Hemken, P., Z.-Q. Wang, and S. Gluck. 1990. Role of 31 k subunit in targeting renal $\mathrm{H}^{+}$ATPase to brush border. Kidney Int. 37:225a. (Abstr.)

50. Yurko, M., and S. Gluck. 1987. Production and characterization of a monoclonal antibody to vacuolar $\mathrm{H}^{+}$ATPase of renal epithelia. J. Biol. Chem 262:15770-15779.
51. Alper, S., J. Natale, S. Gluck, H. Lodish, and D. Brown. 1989. Intercalated cell subtypes in rat kidney collecting duct defined using antibodies against erythrocyte band 3 and renal vacuolar $\mathrm{H}^{+}$ATPase. Proc. Natl. Acad. Sci. USA. 86:54295433.

52. Hansen, G. P., Tisher, C. C., and R. R. Robinson. 1980. Response of the collecting duct to disturbances in acid-base and potassium balance. Kidney Int. 17:326-337.

53. Verlander, J. W., K. M. Madsen, and C. C. Tisher. 1987. Effect of acute respiratory acidosis on two populations of intercalated cells in rat cortical collecting duct. Am. J. Physiol. 253:F1142-F1156.

54. Verlander, J. W., K. M. Madsen, P. S. Low, D. P. Allen, and C. C. Tisher. 1988. Immunocytochemical localization of band 3 protein in the rat collecting duct. Am. J. Physiol. 255:F115-F125.

55. Lonnerholm, G., and Y. Ridderstrale. 1980. Intracellular distribution of carbonic anhydrase in the rat kidney. Kidney Int. 17:162-174.

56. Drenckhahn, D., K. Schluter, D. P. Allen, and V. Bennett. 1985. Colocalization of band 3 with ankyrin and spectrin at the basal membrane of intercalated cells in the rat kidney. Science (Wash. DC). 230:1287-1289.

57. Schuster, V. J., S. M. Bonsib, and M. L. Jennings. 1986. Two types of collecting duct mitochondria-rich (intercalated) cells: lectin and band 3 cytochemistry. Am. J. Physiol, 251:C347-C355.

58. Welling, L. W., A. P. Evan, and D. J. Welling. 1981. Shape of cells and extracellular channels in rabbit collecting ducts. Kidney Int. 20:211-222.

59. Ridderstrale, Y., M. Kashgarian, B. Koeppen, G. Giebisch, D. Stetson, T. Ardito, and B. Stanton. 1988. Morphological heterogeneity of the rabbit collecting duct. Kidney Int. 34:655-670.

60. McKinney, T. D., and K. K. Davidson. 1988. Effects of respiratory acidosis on $\mathrm{HCO3}^{-}$transport by rabbit collecting tubules. Am. J. Physiol. 255:F656F665.

61. Cannon, C., J. Van Adelsberg, S. Kelly, and Q. Al-Awqati. 1985. Carbondioxide-induced exocytotic insertion of $\mathrm{H}^{+}$ATPase in turtle bladder: role of cell $\mathrm{pH}$ and calcium. Nature (Lond.). 314:443-446.

62. Van Adelsberg, J., and Q. Al-Awqati. 1986. Regulation of cell pH by $\mathrm{Ca}^{+2}$-mediated exocytotic insertion of $\mathrm{H}^{+}$ATPases. J. Cell Biol. 102:1638-1645.

63. Weiner, D., and L. L. Hamm. 1990. Regulation of intracellular pH in the rabbit cortical collecting tubule. J. Clin. Invest. 85:274-281.

64. Breyer, M. D., and H. R. Jacobson. 1989. Regulation of rabbit medullary collecting duct cell pH by basolateral $\mathrm{Na}^{+} / \mathrm{H}^{+}$and $\mathrm{Cl}^{-} /$base exchange. J. Clin Invest. 84:996-1004.

65. Hays, S., J. P. Kokko, and H. R. Jacobson. 1986. Hormonal regulation of proton secretion in rabbit medullary collecting duct. J. Clin. Invest. 78:12791286.

66. Paillard, M., and M. Bichara. 1989. Peptide hormone effects on urinary acidification and acid-base balance: PTH, ADH, and glucagon. Am. J. Physiol. 256:F973-F985.

67. Mercier, O., M. Bichara, M. Delahousse, A. Prigent, F. Leviel, and $M$ Paillard. 1989. Effects of glucagon on $\mathrm{H}^{+}-\mathrm{HCO}^{-3}$ transport in Henle's loop, distal tubule, and collecting ducts in the rat. Am. J. Physiol. 257:F1003-F1014.

68. Clapp, W. L., K. M. Madsen, J. W. Verlander, and C. C. Tisher. 1987. Intercalated cells of the rat inner medullary collecting duct. Kidney Int. 31:10801087.

69. Madsen, K. M., W. L. Clapp, and J. W. Verlander. 1988. Structure and function of the inner medullary collecting duct. Kidney Int. 34:441-454.

70. Wingo, C. S., and S. G. Straub. 1989. Active proton secretion and potassium absorption in the rabbit outer medullary collecting duct. J. Clin. Invest. $84: 361-365$.

71. Stetson, D. L., and P. R. Steinmetz. 1986. Correlation between apical intramembrane particles and $\mathrm{H}^{+}$secretion rates during $\mathrm{CO}_{2}$ stimulation in turtle bladder. Pflügers Arch. 407(Suppl. 2):S80-S84.

72. Stetson, D. L., and P. R. Steinmetz. 1983. Role of membrane fusion in $\mathrm{CO}_{2}$ stimulation of proton secretion by turtle bladder. Am. J. Physiol. 245:C11$\mathrm{C} 120$.

73. Gluck, S., C. Cannon, and Q. Al-Awqati. 1982. Exocytosis regulates urinary acidification in turtle bladder by rapid insertion of $\mathrm{H}^{+}$pumps into the luminal membrane. Proc. Natl. Acad. Sci. USA. 79:4327-4331.

74. Schwartz, G. J., and Q. Al-Awqati. 1985. Carbon dioxide causes exocytosis of vesicles containing $\mathrm{H}^{+}$pumps in isolated perfused proximal and collecting tubules. J. Clin. Invest. 75:1638-1644.

75. Good, D. W. 1990. Adaptation of $\mathrm{HCO}_{3}$ and $\mathrm{NH}_{4}^{+}$transport in rat MTAL: effects of chronic metabolic acidosis and $\mathrm{Na}^{+}$intake. Am. J. Physiol. 258:F1345-F1353. 